\title{
RESEARCH ON EMULSION MIST GENERATION IN THE CONDITIONS OF MINIMUM QUANTITY COOLING LUBRICATION (MQCL)
}

\author{
Radoslaw W. Maruda, Eugene Feldshtein, Stanislaw Legutko, Grzegorz, M. Krolczyk
}

Original scientific paper

The paper presents the effect of emulsion mist generation parameters and the distance of the nozzle from the contact zone of the cutting wedge with the workpiece on the diameter and number of droplets supplied into the cutting zone. The conditions of emulsion mist generation, in which all the droplets supplied to the cutting zone in a given time, are evaporated in this time. An analysis of heat flow in the MQCL method was presented and it was proved that the air flow and the distance of the nozzle from the cutting zone have the most significant effect on the diameter of droplets.

Keywords: droplets flow; heat flow; Minimal Quantity Cooling-Lubrication (MQCL)

Istraživanje stvaranja emulzijske izmaglice u uvjetima rashladnog podmazivanja s minimalnom količinom (MQCL)

Izvorni znanstveni članak

U radu se opisuje učinak parametara stvaranja emulzijske izmaglice i udaljenosti mlaznice od kontaktne površine reznog klina s obratkom na promjer i broj kapljica dospjelih u zonu rezanja. Dati su uvjeti stvaranja emulzijske izmaglice u kojoj su sve kapljice, dovedene u zonu rezanja u datom vremenu, u to vrijeme isparile. Opisana je analiza protoka topline u MQCL metodi i dokazano je da protok zraka i udaljenost mlaznice od zone rezanja imaju najvažniji učinak na promjer kapljica.

Keywords: protok kapljica; protok topline; rashladno podmazivanje s minimalnom količinom

\section{Introduction}

Sustainable manufacturing, i.e., the creation of manufactured products through economically-sound processes that minimize negative environmental impacts while conserving energy and natural resources, is the most significant recent trend in industry. The product quality [1, 2], enhancement of employee, community, environmental and product safety is of crucial importance. The key methods of improving the environmental safety of manufacturing processes is a reduction of pollutants generated during processing, such as for instance cooling/lubrication fluids. Benefits brought by a reduction of the amount of cutting fluids involved in machining operations are obvious, therefore the methods which use minimum quantities of cooling and lubrication agents or minimum quantities of lubricants for processing (Minimum Quantity Cooling Lubrication or MQCL and Minimum Quantity Lubrication or MQL, respectively) are a promising alternative to traditional methods of cooling [3].

The fundamental requirements of both methods concern the generation of an optimal fluid-air mixture with the smallest possible sizes of droplets which will secure good moistening of the cutting wedge. The diameter of active medium particles which will get into the atmosphere should not exceed $5 \mu \mathrm{m}$, otherwise the hazard of lung diseases may increase [4]. It is also important to direct the medium into the cutting zone where the tribological conditions are most difficult. The neogenic layer of metal, uncovered by the cutting wedge, due to a high temperature can get oxidized relatively easily, therefore it is of importance to protect it effectively. The sprayed fluid (mist) evaporates more quickly than a dense stream of fluid and thus absorbs more heat [5]. One of the main technological challenges is to create such a surface that would allow condensation and evacuation of the droplets to take place in a continuous manner. The volume of individual droplets is also of significance in this case, since smaller droplets will evaporate from the cutting zone more quickly, thus more heat will be evacuated [6].

Even though the methods referred to above are very promising for many machining applications $[7 \div 10]$, some of the fundamental issues related to their implementation, i.e., the conditions of generating the "active medium-air" mixture in the MQCL method have not been fully investigated yet [11]. Examples of experimental investigations about reducing the use of cooling lubricant substances in turning processes can be found in the open literature $[12 \div 15]$, but these publications do not mention the problems related to the cooling conditions and heat flow in the cutting zone. Therefore, it is of significant importance for an effective choice of conditions of emulsion mist generation and supply to determine correctly the droplet sizes, the distance of the nozzle from the cutting zone [16] as well as the pressure of air passing through the nozzle $[17,18]$.

The aim of this study was to specify in detail the conditions of emulsion mist generation in the MQCL method in relation to the flow of active components, the flow of the carrying medium (compressed air) and the location of the nozzle, and also to determine how these factors affect the conditions of heat exchange in the cutting zone.

\section{Material and methods \\ 2.1 Active medium}

A concentrate of OPORTET RG-2 emulsion was used as an active medium. It is a universal agent used in turning, milling, threading. The concentrate does not lose its performance characteristics for a long period of time and does not contain such compounds as nitrates, chlorine, formaldehydes. It is a water-soluble agent and 
its concentration in water was $2 \%$ when the emulsion was prepared.

\subsection{Experimental procedure}

The research on the conditions of emulsion mist generation consisted in determining the ranges of emulsion flow and compressed air flow and in defining diameters and number of droplets on the area unit of 1 $\mathrm{mm}^{2}$ as well as the concentration of the active medium in $1 \mathrm{~m}^{3}$ of emulsion mist.

The GAV 1500 unit for generating emulsion mist was used for tests (Fig. 1). This unit has the nozzles assemble included two air nozzles of $0,9 \mathrm{~mm}$ diameter and one emulsion nozzle of $1,35 \mathrm{~mm}$ diameter.

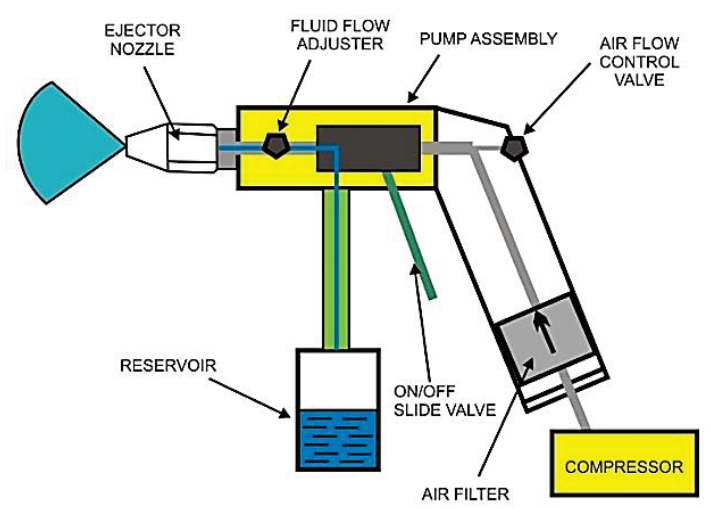

Figure 1 The scheme of GAV 1500 unit

During calibration of the nozzles of emulsion mist generator the following ranges were used: volumetric flow of air $P=4,7 \div 6,9 \mathrm{~m}^{3} / \mathrm{h}$ and emulsion mass flow $E$ $=1,8 \div 3,6 \mathrm{~g} / \mathrm{min}$. The pressure of the compressed air was $2 \mathrm{MPa}$. The distance between the nozzle and the zone of contact between the cutting wedge and the workpiece material was in the range from $0,3 \mathrm{~m}$ to $0,5 \mathrm{~m}$.

The volumetric flow of air was measured with the PT12 rotameter of the $4^{\text {th }}$ class of accuracy in accordance with the DIN standard and with the accuracy of measurements of $\pm 3 \%$. The emulsion mass flow was measured with a precision balance of the weighing accuracy of $0,1 \mathrm{mg}$.

The number and diameters of droplets supplied into the cutting zone were measured with the MM 200 measuring microscope and the measurement accuracy was $\pm 5 \%$.

\section{Results and discussion}

\subsection{Number and diameters of droplets in the contact zone}

The results of measurements of the diameters and the number of droplets were studied with the use of descriptive statistical methods. Fig. 2 shows histograms of diameter dispersion, whereas Tab. 1 includes some of the results of statistical analysis.

While analysing the histograms obtained it can be noticed that distributions of droplet diameters are similar to normal.

After a mathematical treatment of the results of experimental tests equations of multidimensional regression were obtained which determine the number of droplets $N$ which are found in $1 \mathrm{~mm}^{2}$ of the area and their average diameter $D$ depending on the conditions of mist generation:

$$
\begin{aligned}
& N=2,56 \cdot L^{0,58} \cdot E^{0,19} \cdot P^{1,772}, \\
& D=35,9 \cdot L^{-2,368} \cdot E^{1,94} \cdot P^{-2,914}
\end{aligned}
$$

where: $L$ - the distance of the nozzle from the cutting zone $(\mathrm{m}) ; E-$ emulsion mass flow $(\mathrm{g} / \mathrm{min}) ; P-$ volumetric flow of air $\left(\mathrm{m}^{3} / \mathrm{h}\right)$

The above relations are illustrated in Fig. 3. The droplets decrease in their diameter together with the increased distance of the nozzle from the zone of contact between the cutting wedge and the workpiece material. The diameter of droplets reaches the highest value at the distance of $0,3 \mathrm{~m}$ for the maximum emulsion mass flow $(3,6 \mathrm{~g} / \mathrm{min})$. The amount of flowing air has a similar effect on the droplet diameters as the distance has. Once the air flow is increased, the diameters of droplets decrease. It can be seen in the curve presented in Fig. 3 a that the flow of emulsion also has a significant effect on the diameter of droplets. Once it grows, the diameter of droplets increases, but not as much as in the case of a change in the air flow.

Fig. 4 illustrates the effect of individual parameters of mist generation on the number of droplets falling within 1 $\mathrm{s}$ on the area of $20 \mathrm{~mm}^{2}$ (which corresponds to the contact area between the chip, the rake face and the adjacent machined surface [19]). The number of droplets increases together with increasing the flow of air. It is highest for the emulsion flow of $3,6 \mathrm{~g} / \mathrm{min}$. The lowest number of droplets was observed at the distance of the nozzle of 0,3 $\mathrm{m}$ and emulsion flow of $1,6 \mathrm{~g} / \mathrm{min}$. Together with an increase in the distance the number of droplets grows (it is highest at the maximum distance of the nozzle, i.e., 0,5 $\mathrm{m})$. The flow of emulsion has the least significant effect on the number of droplets.

\subsection{Analysis of heat flow in the MQCL method}

In the MCQL method, the droplets are first heated up to their saturation temperature $Q_{\mathrm{s}}$, and then are evaporated. For the first part of the process the heat balance equation is of the following form [20]:

$$
\frac{\pi \cdot D^{2}}{4} \cdot \alpha \cdot\left(\Theta_{\mathrm{s}}-\Theta_{0}\right) \cdot t_{1}=c_{v} \cdot \frac{\pi \cdot d^{3}}{6} \cdot\left(\Theta_{\mathrm{s}}-\Theta_{0}\right)
$$

where: $t_{1}-$ the heating time; $\alpha$ - the heat penetration coefficient; $c_{\mathrm{v}}$ - the volumetric specific heat of water; $\Theta_{0}$ - the temperature of the medium at nozzle outlet; $D$ - the droplet diameter at the contact surface; $d-$ the droplet diameter in air.

On transformation of this formula, we obtain the droplet heating time:

$t_{1}=\frac{2}{3} \cdot \frac{c_{v} \cdot d}{\alpha \cdot m^{2}}$

where: $m=D / d$ - the coefficient of droplet deformation.

After microscopic examinations of the droplet diameter it was observed that a droplet of a fluid when hitting a hard body gets deformed in such a way that the 
diameter of contact "mark" between the droplet and the body surface is [18]:

$D=2 \cdot\left[\frac{3 V_{\mathrm{dr}}}{4 \pi}\right]^{\frac{1}{3}}$

where: $V_{\mathrm{dr}}-$ the droplet volume in air.
The heat balance equation for the process of droplet evaporation is as follows [20]:

$$
\frac{\pi D^{2}}{4} \alpha\left(\Theta_{\mathrm{hs}}-\Theta_{\mathrm{s}}\right) t_{2}=\frac{\pi d^{3}}{6} \rho r
$$

where: $t_{2}$ - time of droplet evaporation $r$ - water evaporation heat; $\Theta_{\mathrm{hs}}$ - the heated surface temperature [19]; $\rho$-water density.

Table 1 Examples of statistical analysis of diameter dispersion of emulsion mist droplets

\begin{tabular}{|c|c|c|c|c|c|c|c|c|}
\hline No. & $\begin{array}{c}\text { Distance of } \\
\text { nozzle from } \\
\text { cutting zone } \\
/ \mathrm{m}\end{array}$ & $\begin{array}{c}\text { Emulsion } \\
\text { mass flow / } \\
\mathrm{g} / \mathrm{min}\end{array}$ & $\begin{array}{c}\text { Volumetric flow } \\
\text { of air } / \mathrm{m}^{3} / \mathrm{h}\end{array}$ & $\begin{array}{c}\text { Number of } \\
\text { droplets per } \\
1 \mathrm{~mm}^{2}\end{array}$ & $\begin{array}{c}\text { Average } \\
\text { diameter } \\
\text { of droplets / } \\
\mu \mathrm{m}\end{array}$ & $\begin{array}{c}\text { Minimum } \\
\text { diameter } \\
\text { of droplets / } \\
\mu \mathrm{m}\end{array}$ & $\begin{array}{c}\text { Maximum } \\
\text { diameter } \\
\text { of droplets / } \mu \mathrm{m}\end{array}$ & $\begin{array}{c}\text { Standard error } \\
/ \mu \mathrm{m}\end{array}$ \\
\hline 1 & 0,3 & 1,8 & 4,7 & 29 & 23,7 & 19 & 32 & 3,242 \\
\hline 2 & 0,3 & 3,6 & 5,05 & 23 & 16,4 & 12 & 22 & 3,072 \\
\hline 3 & 0,4 & 2,5 & 4,7 & 30 & 20,8 & 12 & 32 & 5,671 \\
\hline 4 & 0,5 & 3,6 & 4,7 & 30 & 13,3 & 6 & 28 & 4,968 \\
\hline
\end{tabular}

a)

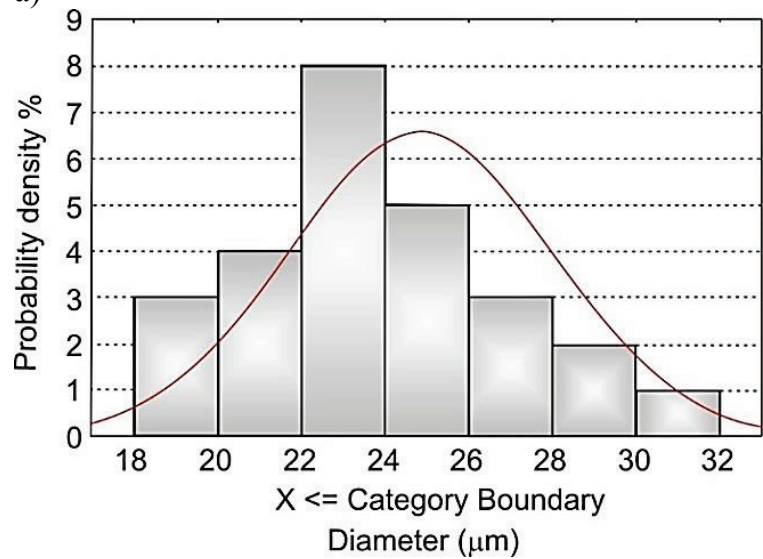

c)

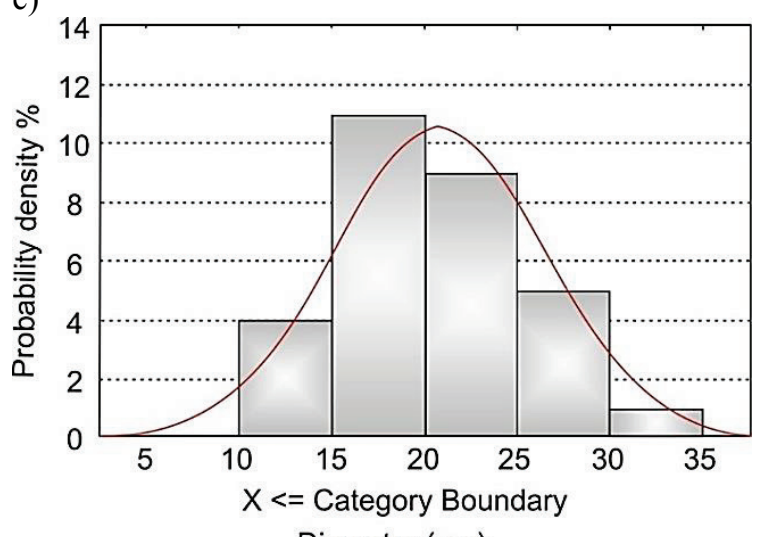

b)

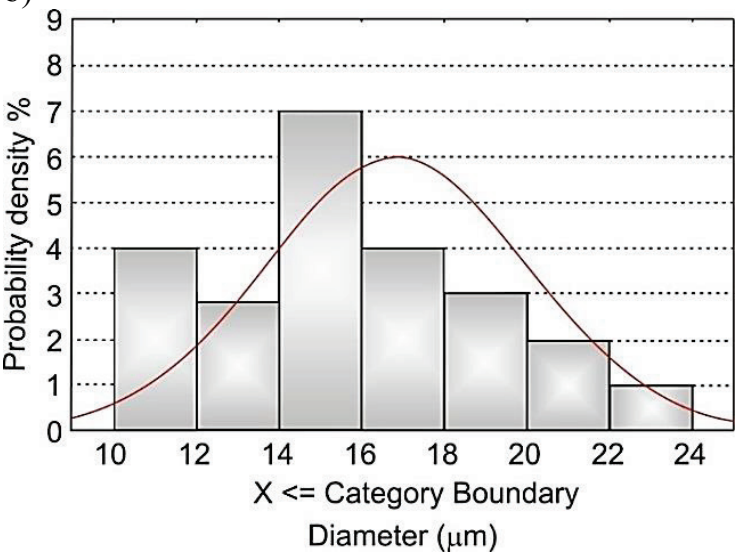

d)

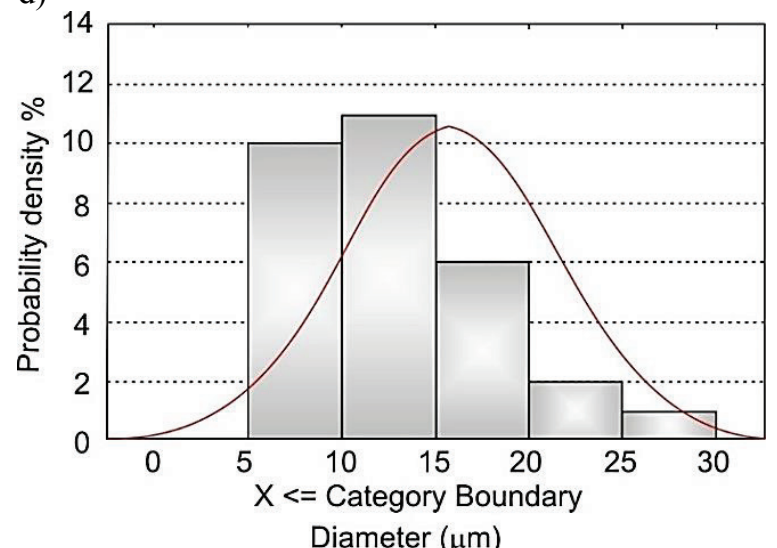

Figure 2 Histogramsof droplet diameter dispersions at: a) $L=0,3 \mathrm{~m}, E=3,6 \mathrm{~g} / \mathrm{min}, P=4,7 \mathrm{~m} / \mathrm{h}$; b) $L=0,3 \mathrm{~m} ; E=3,6 \mathrm{~g} / \mathrm{min}, P=5,05 \mathrm{~m}^{3} / \mathrm{h}$; c) $L=0,4 \mathrm{~m} ; E=2,5 \mathrm{~g} / \mathrm{min}, P=4,7 \mathrm{~m}^{3} / \mathrm{h}$; d) $L=0,5 \mathrm{~m} ; E=3,6 \mathrm{~g} / \mathrm{min}, P=4,7 \mathrm{~m}^{3} / \mathrm{h}$

The value of $\Theta_{\mathrm{hs}}$ was taken as the average temperature of the "the chip-cutting wedge-machined element" contact zone and the temperatures of the areas of the machined element and the chip closest to this zone.

$t_{2}=\frac{2}{3} \cdot \frac{\rho r d}{\alpha m^{2}\left(\Theta_{\mathrm{hs}}-\Theta_{\mathrm{s}}\right)}$.

The total evaporation time for a single droplet is: $t=t_{1}+t_{2}$

Using Eqs. (3) $\div(8)$ and taking into consideration the diameter and number of droplets falling on a heated surface it is possible to determine the conditions of evaporation of all the droplets. Changes in the evaporation time in relation to the emulsion mass flow, droplet diameters and the volumetric flow of air $P=4,7 \div$ $6,9 \mathrm{~m}^{3} / \mathrm{h}$ are illustrated in Fig. 5 . 
a)

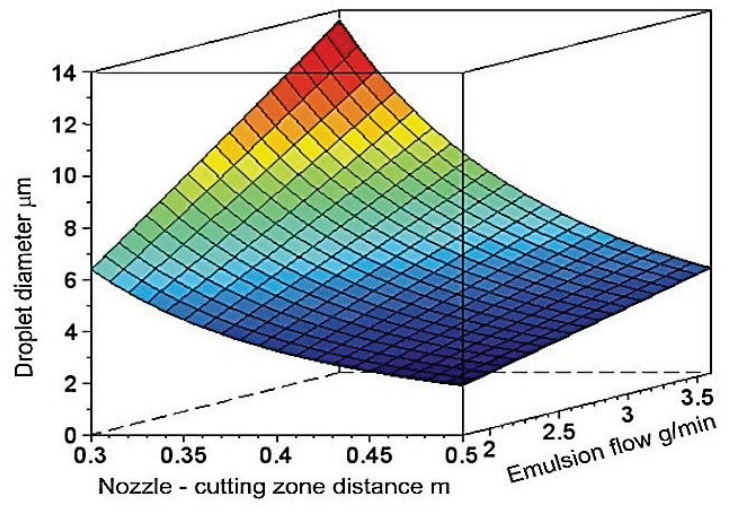

b)

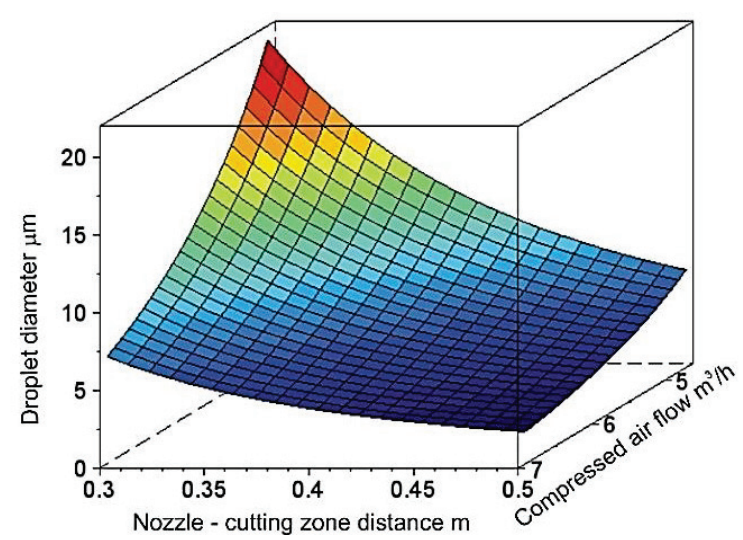

c)

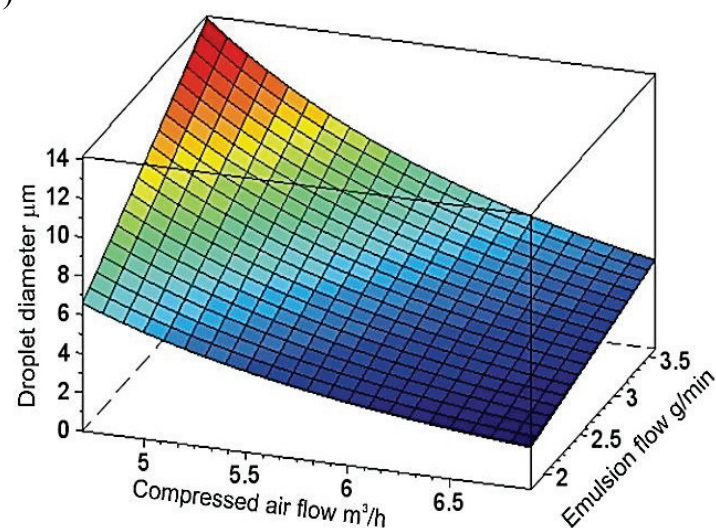

Figure 3 Relations between the diameter of droplets and: a) the distance of the nozzle from the cutting zone and emulsion flow (for $\left.\left.P=6 \mathrm{~m}^{3} / \mathrm{h}\right) ; \mathrm{b}\right)$ the distance of the nozzle from the cutting zone and compressed air flow (for $E=2,6 \mathrm{~g} / \mathrm{min}$ ); c) compressed air flow and emulsion flow (for $L=0,4 \mathrm{~m}$ )

a)

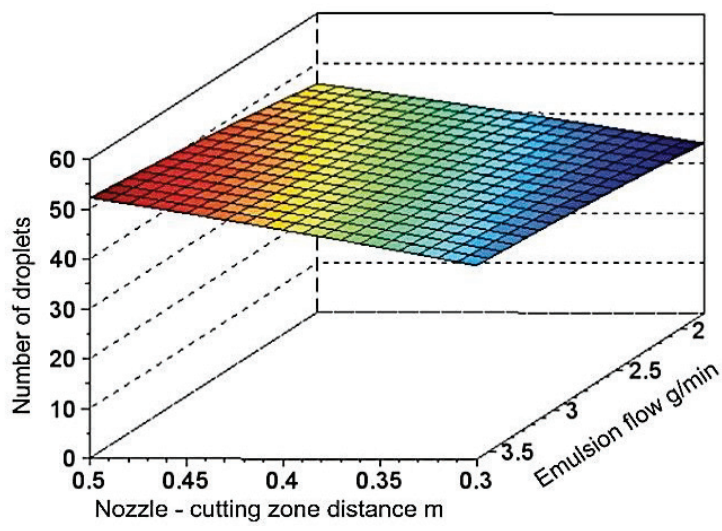

b)

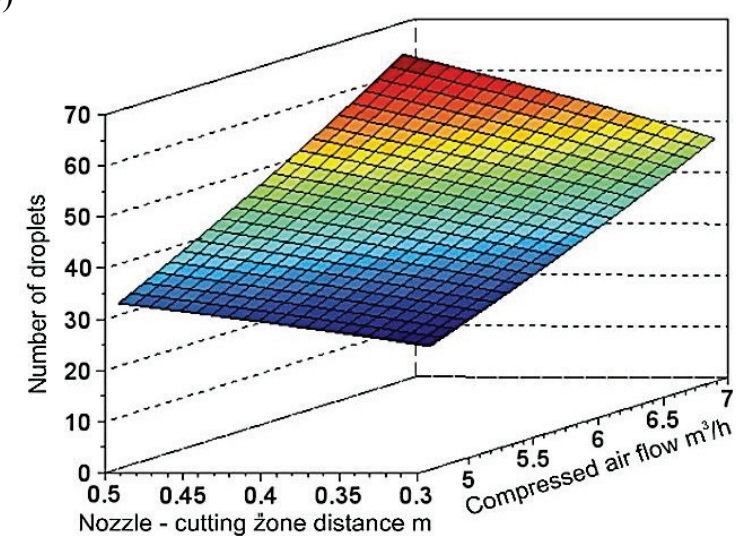

c)

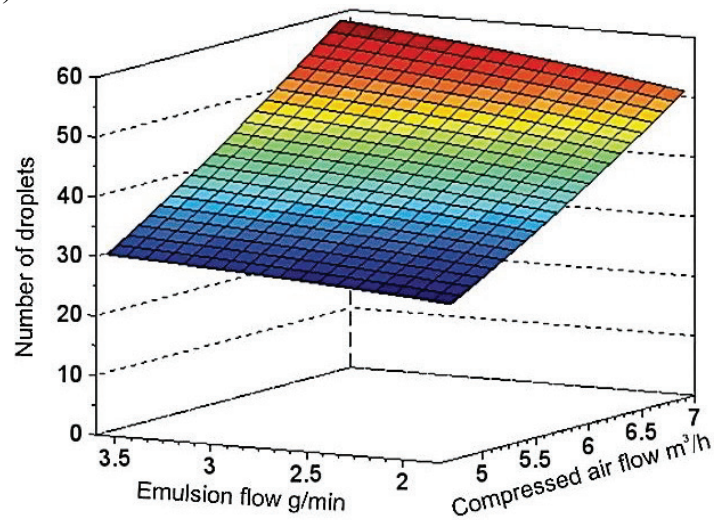

Figure 4 Relations between the number of droplets and a) the distance of the nozzle from the cutting zone and the emulsion flow (for $\left.\left.P=6 \mathrm{~m}^{3} / \mathrm{h}\right) ; \mathrm{b}\right)$ the distance of the nozzle from the cutting zone and compressed air flow (for $E=2,6 \mathrm{~g} / \mathrm{min}$ ); c) emulsion flow and compressed air flow (for $L=0,4 \mathrm{~m}$ ) 


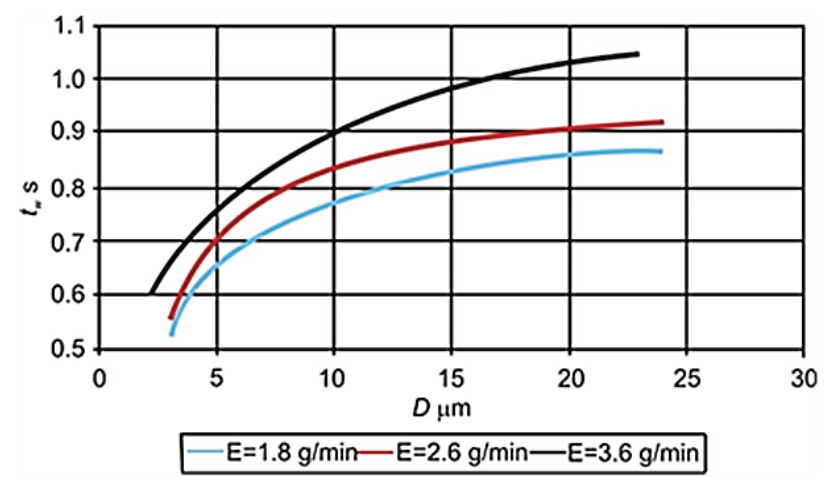

Figure 5 Evaporation time of droplets falling on the heated surface in $1 \mathrm{~s}$ in relation to droplet diameter and emulsion mass flow

\section{Conclusions}

1) On the basis of analyses of measurements of the number as well as the diameters of droplets and the heat flow in the cutting zone the following conclusions can be drawn:

2) The distance of the nozzle from the cutting zone and compressed air flow has the most significant impact on the droplet diameter.

3) Changes in the emulsion flow have a less pronounced effect on the droplet diameters.

4) An increase in the volumetric air flow and an increase in the distance of the nozzle from the cutting zone results in an increase in the number of droplets, whereas their diameters decrease.

5) Droplets of the diameter less than $5 \mu \mathrm{m}$ are generated when the volumetric air flow is above $6 \mathrm{~m}^{3} / \mathrm{h}$. This is of importance on account of operators' health. Such a diameter of droplets has the least negative effect on human health.

6) Once the diameters and number of droplets falling on the cutting edge are known, it is possible to choose such conditions of mist generation in which all droplets falling on the heated surface in $1 \mathrm{~s}$ are evaporated from this surface: $E$ less than $3,6 \mathrm{~g} / \mathrm{min}$ and $P$ less than $5,0 \mathrm{~m}^{3} / \mathrm{h}$.

\section{References}

[1] Barkallah, M.; Louati, J.; Haddar, M. Evaluation of Manufacturing Tolerance Using a Statistical Method and Experimentation. // International Journal of Simulation Modelling. 11, 1(2012), pp. 5-16. DOI: 10.2507/IJSIMM11(1)1.194

[2] Simunovic, G.; Simunovic, K.; Saric, T. Modelling and Simulation of Surface Roughness in Face Milling. // International Journal of Simulation Modelling. 12, 3(2013), pp. 141-153. DOI: 10.2507/IJSIMM12(3)1.219

[3] Kammermeier, D.; Kauper, H.; Borchert, W. Die zweite Generation der Trockenzerspanung heißt High Performance Cutting (HPC). // Spanende Fertigung, Vulkan-Verlag / Essen, 2001, pp. 136-150.

[4] Konold, T. Maschinentechnik fur die Trockenbearbeitung, VDI-Z. // Integriete Produktion. 4, (2001), pp. 61-63.

[5] Miljkovic, N.; Enright, R.; Nam, Y.; Lopez, K.; Dou, N., Sack, J.; Wang, E. N. Jumping-Droplet-Enhanced Condensation on Scalable Superhydrophobic Nanostructured Surfaces. // Nano Lett. 13, (2013), pp. 179187. DOI: $10.1021 / \mathrm{nl} 303835 \mathrm{~d}$
[6] Lauro, C. H.; Brandão, L. C.; Vale, T. J. S.; Christóforo, L. A. An approach to define the heat flow in drilling with different cooling systems using finite element analysis. // Advances in Mechanical Engineering. (2013), ID 612747.

[7] Rahman, M.; Kumar, A. S.; Salam, M. U. Experimental evaluation on the effect of minimal quantities of lubricant in milling. // International Journal of Machine Tools and Manufacture, 42, (2002), pp. 539-547. DOI: 10.1016/S08906955(01)00160-2

[8] Varadarajan, A. S.; Philip, P. K.; Ramamoorthy, B. Investigations on hard turning with minimal cutting fluid application (HTMF) and its comparison with dry and wet turning. // International Journal of Machine Tools and Manufacture. 42, (2002), pp. 193-200. DOI: 10.1016/S08906955(01)00119-5

[9] Sharma, V. S.; Dogra, M.; Suri, N. M. Cooling techniques for improved productivity in turning. // International Journal of Machine Tools and Manufacture. 49, (2009), pp. 435-453. DOI: 10.1016/j.jimachtools.2008.12.010

[10] Kundrak, J.; Varga, G. Use of coolants and lubricants in hard machining. // Tehnicki vjesnik-Technical Gazette. 20, 6(2014), pp. 1081-1086

[11] Park, K.-H.; Olortegui-Yume, J.; Joshi, S.; Kwon, P.; Yoon, M.-C.; Lee, G.-B.; Park, S.-B. Measurement of droplet size and volumes for minimum quantity lubrication (MQL). // International Conference on Smart Manufacturing Application /Goyang-si, Korea (South), 2008.

[12] Pusavec, F.; Stoic, A.; Kopac, J. The role of cryogenics in machining processes. // Tehnički vjesnik-Technical Gazette. 16, 4(2009), pp. 3-10.

[13] Krolczyk, G.; Legutko, S.; Nieslony, P.; Gajek, M. Study of the surface integrity microhardness of austenitic stainless steel after turning. // TehničkiVjesnik-Technical Gazette, 21, 6(2014), pp. 1307-1311

[14] Krolczyk, G.; Legutko, S. Investigations into Surface Integrity in the Turning Process of Duplex Stainless Steel. // Transactions of FAMENA. 38, (2014), pp. 77-82.

[15] Khan, M. M. A.; Mithu, M. A. H.; Dhar, N. R. Effects of minimum quantity lubrication on turning AISI 9310 alloy steel using vegetable oil-based cutting fluid. // Journal of Materials Processing Technology. 209, (2009), pp 55735583. DOI: 10.1016/j.jmatprotec.2009.05.014

[16] Hadad, M.; Sadeghi, B. Minimum quantity lubricationMQL turning of AISI 4140 steel alloy. // Journal of Cleaner Production. 54, (2013), pp. 332-343. DOl: 10.1016/j.jclepro.2013.05.011

[17] Sarıkaya, M.; Güllü, A. Taguchi design and response surface methodology based analysis of machining parameters in CNC turning under MQL. // Journal of Cleaner Production. 65, (2014), pp. 604-616. DOI: 10.1016/j.jclepro.2013.08.040

[18] Park, K. H.; Olortegui-Yume, J.; Yoon, M. Ch.; Kwon, P. A study on droplets and their distribution for minimum quantity lubrication. // International Journal of Machine Tools and Manufacture. 50, (2010), pp 824-833. DOI: 10.1016/j.jijmachtools.2010.05.001

[19] Yashcheritsyn, P.; Feldshtein, E.; Kutser, V.; Sharaf, A.; Diallo, U. The modelling and investigation of thermal processes in the technological machining system using finite element method. // Proceedings of the Belarussian Academy of Sciences, Series of Physical-Technical Sciences. 1, (1993),pp. 93-99 (in Russian).

[20] Ahsan, A. Convection and Conduction Heat Transfer, Ed. Rijeka, InTech, 2011. 


\section{Authors' addresses}

Radoslaw W. Maruda, PhD. Eng.

Eugene Feldshtein, Prof. DSc. PhD. Eng.

Faculty of Mechanical Engineering

University of Zielona Gora

4 Prof. Z. Szafrana street, 65-516 Zielona Gora, Poland

E-mail: r.maruda@ibem.uz.zgora.pl

E-mail: e.feldshtein@ibem.uz.zgora.pl

Stanislaw Legutko, Prof. DSc. PhD. Eng., Prof.h.c.

Faculty of Mechanical Engineering and Management

Poznan University of Technology

3 Piotrowo Street, 60-965 Poznan, Poland

E-mail: stanislaw.legutko@put.poznan.pl

Grzegorz, M. Krolczyk, PhD.

Faculty of Production Engineering and Logistics

Opole University of Technology

76 Prószkowska Street, 45-758 Opole, Poland

E-mail: g.krolczyk@po.opole.pl 